\title{
SPATIAL PATTERN, DENSITY AND CHARACTERISTICS OF LARGE WOOD IN CONNECTICUT STREAMS: IMPLICATIONS FOR STREAM RESTORATION PRIORITIES IN SOUTHERN NEW ENGLAND
}

\author{
K. H. COSTIGAN* AND M. D. DANIELS \\ Department of Geography, Kansas State University, Manhattan, Kansas USA
}

\begin{abstract}
Many streams have been modified so extensively that river managers do not have clear reference conditions to frame targets for stream restoration. Large woody debris (LWD) has long been recognized as an important influence on both geomorphic and ecologic processes in stream channels; however, there have been few studies of LWD dynamics in New England. Although this region is heavily forested today, the forest is predominantly young (70-90 years old) regrowth following a historical episode of severe deforestation. This study presents the results of an extensive census of LWD and associated stream characteristics in over 16 river kilometres of northeastern Connecticut streams and represents the first reported inventory of wood loading and sorting in Southern New England. Results of this study indicate that wood loading and jam frequencies in the study region are low: 2.5-17.8 and 0.5-5.51 per $100 \mathrm{~m}$, respectively. Orientation of LWD is predominantly parallel to flow, an indication that these streams are not retaining organic matter or sediment, which has important geomorphic and ecologic implications. Results imply that stream recruitment of LWD is still lagging from the massive forest conversions of the 18th and 19th centuries. Given the low wood loadings observed in the study reaches, manual wood addition and continued forest regeneration would likely improve both habitat diversity and organic matter and fine sediment retention in these systems. Copyright @ 2011 John Wiley \& Sons, Ltd.
\end{abstract}

KEY wORDS: large woody debris; spatial distribution; wood jams; in-stream wood; stream restoration

Received 4 March 2011; Revised 18 July 2011; Accepted 27 July 2011

\section{INTRODUCTION}

Across the globe, fluvial structures and dynamics have been severely altered by widespread land use changes and direct river channel modifications. These physical changes have resulted in reduced ecological function and habitat simplification (e.g. Meyer et al., 2007; Nilsson et al., 2007). In attempts to address this ecosystem decline, large financial investments are made in river restoration projects (e.g. Bernhardt et al., 2005). Yet, in many cases, an appropriate reference target for restoration is absent because of the spatial and temporal extents of the disturbances. Such is the case in Southern New England, where most streams have been radically impacted by human activities for such a long time that river managers do not have clear reference conditions with which to frame targets for stream restoration. This problem is particularly acute with respect to understanding what predisturbance wood loadings might have been for the region's streams. New England was settled extensively after colonization and underwent widespread deforestation driven by conversion of forests to agri-

*Correspondence to: K. H. Costigan, Department of Geography, Kansas State University, 118 Seaton Hall, Manhattan, KS 66506, USA.

E-mail: costigan@k-state.edu cultural production, particularly to support grazing animals. Hardwoods also were logged extensively to fuel smelting of iron and brass, and hemlocks were logged and stripped of their bark for use in tanneries. These landscape level pressures resulted in the virtual elimination of old growth forests in Southern New England. Since the widespread agricultural abandonment in the late 19th and early 20th centuries, natural reforestation began but did not produce forests similar to those of pre-European conditions because of continuing low-intensity forests disturbances such as logging (Fuller et al., 1998; Motzkin et al., 1999). New England forests today are a patchwork of young regrowth stands, with the oldest patches still well short of the natural senescence age for common species. In the absence of age-related mortality, wood introduction to streams and rivers is largely dependent on episodic disturbances such as windthrow events, ice storms and bank erosion. The wood load present in Southern New England streams today does not show advanced decay, suggesting a relatively recent introduction to the system. It remains unknown whether the streams were historically cleared by people at the same time the forests were or whether the pre-European in-stream wood load simply transported out or decayed in place.

Large woody debris (LWD) has long been recognized as an important influence on both geomorphic and ecologic 
processes in stream channels. In systems of all orders and gradients, LWD has been shown to affect pool-riffle spacing and forms, channel geometry and channel planform (Robinson and Beschta, 1990a, 1990b; Gregory et al., 1994; Ralph et al., 1994; Gurnell et al., 1995; Montgomery et al., 1995; Richmond and Fausch, 1995; Abbe and Montgomery, 1996; Friedman et al., 1996; Myers and Swanson, 1997; Gurnell and Sweet, 1998; Buffington et al., 2002). LWD also can cause variations in the longitudinal profile of both the stream bed and the water surface by storing sediment, creating scour pools, anchoring pools or scour holes in place, or creating deep backwater pools (Maser and Sedell, 1994; Gurnell and Sweet, 1998).

Large woody debris structures modify the storage and transport of materials including sediment, organic matter and solutes throughout the stream system (Keller and Swanson, 1979; Assani and Petit, 1995; Gippel, 1995; Gurnell and Sweet, 1998), creating areas of low shear stress (Fetherston et al., 1995), increasing the roughness of the bed, increasing the shear stress required to initiate motion of particles, providing up to half of the total flow resistance (Assani and Petit, 1995; Magna and Kirchner, 2000), accumulating and retaining sediment (Raikow et al., 1995; Thompson, 1995; Daniels, 2006), increasing bank stability (Keller and Swanson, 1979) and creating gravel bars (Montgomery et al., 2003). If LWD structures are removed from a system, sediment is released from storage, resulting in rapid increases in sediment transport and export out of the system (Smith et al., 1993; Ralph et al., 1994; Gurnell et al., 1995), potentially leading to geomorphic instability, channel widening, bank erosion (Gippel et al., 1996), erosion of fine sediments from gravel substrates, contraction of pool areas and an overall reduction in physical habitat complexity (Lisle, 1995).

The role that LWD plays in structuring the complexity of physical habitats in streams does not alone fully represent the extent of its importance to stream ecosystem functioning. The input of LWD is a major linkage between aquatic and terrestrial ecosystems. LWD is recognized as an important structural component as well as an important nutrient source for the continuum of nutrient spiraling in stream ecosystems (Bilby and Likens, 1980; Cummins et al., 1983; Lienkaemper and Swanson, 1987) with clear ties to increased biodiversity (Piégay et al., 1999; Beisel et al., 2000; Lester et al., 2007). LWD structures help retain coarse particulate organic matter (CPOM) in the stream system long enough to be processed rather than being flushed downstream in coarse form (Bilby and Likens, 1980; Lamberti et al., 1989; Maser and Sedell, 1994). Any reduction in the organic matter retention capacity of a stream is thought to reduce the system's capability to process CPOM and consequently reduce the energy base of the ecosystem (Bilby and Likens, 1980; Maser and Sedell, 1994; Gurnell et al., 1995).
The orientation and arrangement of wood in streams can influence its functional role in the system. For example, wood orientations that are parallel to flow likely have a greatly reduced retention function compared with orientations perpendicular to flow and can be an indication that the LWD is not retaining organic matter or sediment because of the lack of resistance and associated pool formation (Magilligan et al., 2008). Clustering of LWD into jams influences in-channel hydraulics and channel pattern more than individual wood pieces (Keller and Swanson, 1979), and the density of jamming has been shown to influence the longitudinal geomorphic pattern of the system (Wohl and Jaeger, 2009). Key jam member pieces are those that anchor the debris jam (Keller and Tally, 1979; Nakamura and Swanson, 1993) and are crucial for the development of jams. The presence of jams is thought to be an indicator of wood transport capacity, with a high density of jams suggesting a lower wood transport capacity (Wohl and Jaeger, 2009), and is representative of a balance of recruitment and downstream movement. Jams can substantially increase the residence time of finer organic material by wedging and burying pieces of wood (Gurnell and Sweet, 1998; Cadol and Wohl, 2011) and creating upstream backwater habitats that result in increased organic matter and sediment storage (Daniels, 2006).

The characteristic dimensions of the LWD found in a given fluvial system are dependent on the climate, species, stand age, and forest management history in the environment the LWD was derived (Comiti et al., 2006). There is a long history of removing LWD from larger rivers and streams in the 19th and 20th centuries for navigation and to reduce flooding (Montgomery et al., 2003). However, in smaller streams, LWD loads also were radically altered by widespread land cover changes. In the USA, much of the forests east of the Appalachian Mountains underwent a dramatic conversion to agricultural and grazing lands during the 18th and 19th centuries to be replaced by the modern land cover of expanding second growth forest interspersed with urban settlements. Although many northeastern states are now densely populated, there remain vast areas of lowdensity development in states, such as Connecticut, that are largely covered by second growth forest. Very little old growth forest has survived. Recruitment of LWD is known to lag behind forest regeneration by centuries (Bragg, 2000; Benda et al., 2003); therefore, we hypothesized that current LWD conditions in the Connecticut streams surveyed in this study are lower than those observed in other regions outside the New England region.

Recent reviews of the literature (Cordova et al., 2007; Cadol et al., 2009) documented LWD loadings across many regions and nations with varying forest compositions and age structures, but only very recently have any studies examined LWD loading and dynamics in the Northeastern 
USA where forests are young and wood loadings are conspicuously lower than in other regions of the USA (Magilligan et al., 2008; Warren and Kraft, 2008; Laser et al., 2009; Warren et al., 2009). Although these studies have helped shed light on LWD characteristics in the Northeastern USA (upstate New York and Maine), no LWD census studies have been conducted in Southern New England where both natural vegetation distributions and anthropogenic land use change histories are quite different.

Many have noted that the speed and scale of investment in restoration appear to be resulting in management applications outpacing scientific developments in the fluvial sciences (Kondolf, 1995; Wohl et al., 1995; Bernhardt et al., 2005; Snyder et al., 2009; Wilkins and Snyder, 2010). In the case of large wood, our scientific understanding of loading densities and mechanisms is in its infancy and is based on regionally concentrated studies, whereas wood addition is an increasingly popular restoration strategy (Kasprak et al., 2010). It is with this imbalance in mind that we attempt to address the absence of a contextual understanding of wood loadings in Southern New England streams. We do this by evaluating how wood loadings in representative Southern New England streams compare with studies reported for other regions of the United States. To achieve this, we present the results of an extensive census of LWD and associated stream characteristics in northeastern Connecticut streams. We hypothesized the following: (i) that wood loadings would be among the lowest reported for the USA; and (ii) that there would be few geomorphically influential large pieces of wood or wood accumulations. Finally, we discuss how large wood loading in today's Southern New England streams compare with those observed in other regions and how river managers might use this increased scientific understanding to guide wood addition restoration efforts.

\section{MATERIALS AND METHODS}

\section{Study region}

Over $16 \mathrm{~km}$ of river length were inventoried for LWD in seven Connecticut streams (Figure 1). The study river segments are all part of the larger Thames River watershed in the Eastern Highlands of Connecticut and ultimately drain to the Long Island Sound. Mean annual precipitation is $115 \mathrm{~cm} \pm \mathrm{a}$ standard deviation (SD) of $18.5 \mathrm{~cm}$, with snowfall being a minor component because of the proximity of the Thames River watershed to the Atlantic Ocean (Miller et al., 2002). Each of the study segments are single-thread channels with little lateral mobility within developed floodplains. Stream gradients ranged from 0.009 to $0.1 \%$, and channel widths ranged from 4.22 to $30.3 \mathrm{~m}$ (see Table I for full study site descriptions).
Surficial geology in the watershed is composed of strongly foliated metamorphic bedrock dating to the Paleozoic Era (Abrams and Riley, 2002) and surficial deposits of glacial till ranging from 0 to $15.2 \mathrm{~m}$ thick (Warren and Stone, 1986), although generally less than $4.5 \mathrm{~m}$ thick. Modern day soils are largely developed from a layer of aeolian sand and silts that overlay the glacial till (Stone et al., 2005). Glacial retreat occurred between 18000 and 16000 years ago (Stone and Borns, 1986), and the region continues a glacio-isostatic rebound of $0.9 \mathrm{~mm}$ per year (Koteff et al., 1988). Riparian forests were all classified as mixed northern hardwoods with a mix of coniferous and deciduous trees with no large scale current anthropogenic disturbances documented.

The area did experience a large scale land use and land cover conversion in the 18th and 19th centuries, but since the 1940s, the forests have largely been left to naturally regenerate; however, anthropogenic disturbances to the area are still occurring today. Small run-of-the-river dams (less than 1-20 $\mathrm{m}$ in height) are quite numerous in the region, including within the Thames River watershed (McCusker and Daniels, 2009). These dams are primarily relics of Connecticut's water-powered industry of the $1700 \mathrm{~s}-1900 \mathrm{~s}$ and are increasingly the target of dam removal efforts. Although the Thames River watershed has some of the highest percentages of riparian forest cover in Connecticut, since 1985, there has been a net conversion of riparian cover to urban development (CLEAR, 2006). All of the study reaches selected for this research have well developed forests and no urban development within the riparian zone. Reaches also were selected to minimize road crossings, geological channel confinement and impoundments (including active beaver colonies).

\section{Study design}

Sampled river segments ranged from 576 to $5700 \mathrm{~m}$ and were divided into sampling reaches based on the uniformity of mesohabitats. Mesohabitats were defined based on uniformity of slope, planform configuration, bed material and channel unit types (eg. step-pool, riffle-run). Ten representative measurements of bankfull depths and widths, as identified in the field based on channel morphology, were recorded throughout each reach. For each reach, the gradient, sinuosity, bed material, prominent bank vegetation and floodplain size were determined. Stream segments were classified by watershed areas as defined from the furthest downstream limit of the sampled reach and by the Strahler stream order (Strahler, 1957) as a measure of stream size.

All pieces of LWD contained within the active floodplain, defined as the flat portion of the valley immediately adjacent to the channel that is constructed by the present river under the present climate (Leopold, 1994), and over $0.05 \mathrm{~m}$ in diameter and greater than $0.3 \mathrm{~m}$ in length (Comiti et al., 2006) 

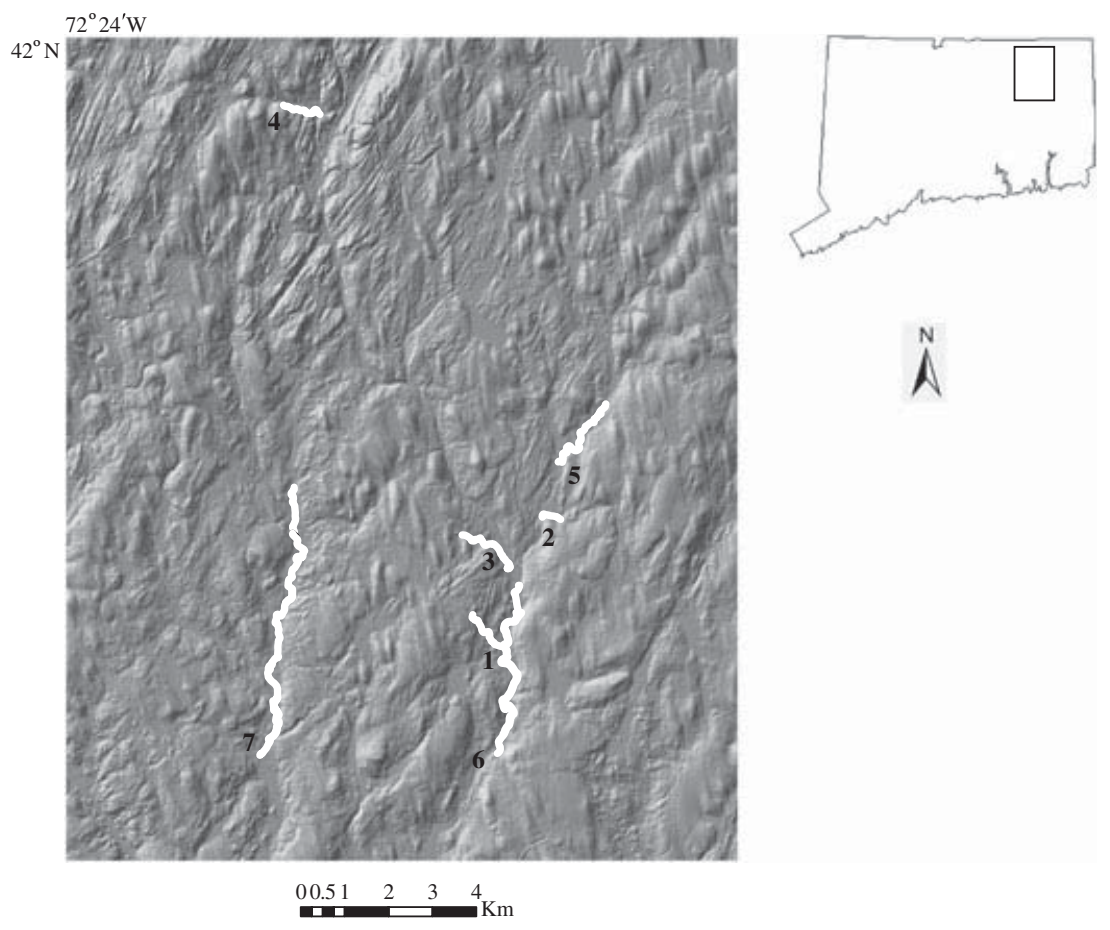

Figure 1. Shaded relief map showing location of study sites in white lines, the streams are numbered as they appear in Table I

were inventoried to document the full range of ecologic and geomorphically important woody debris. For each piece of LWD, we measured mid-length diameter and total length using a caliper and measuring tape, respectively. Volume $\left(V, \mathrm{~m}^{3}\right)$ was calculated based on the mid-length diameter and the length of the log based on the assumption of a cylinder where

$$
V=\pi r^{2} h
$$

$r$ is the mean radius (m) and $h$ is the length (m) of the woody debris. We also recorded the jam status and orientation of the LWD to flow; orientation delineations are as follows, with $180^{\circ}$ being the main flow direction: parallel (A) $337.5-22.5^{\circ}$

Table I. Site characteristics of sampled watersheds

\begin{tabular}{|c|c|c|c|c|c|c|c|}
\hline & $\begin{array}{l}\text { School House } \\
\text { Brook }\end{array}$ & $\begin{array}{l}\text { Goodwin } \\
\text { Brook }\end{array}$ & $\begin{array}{l}\text { Eldridge } \\
\text { Brook }\end{array}$ & $\begin{array}{l}\text { Yale } \\
\text { Forest }\end{array}$ & $\begin{array}{l}\text { Beaver Dam } \\
\text { Brook }\end{array}$ & $\begin{array}{l}\text { Fenton } \\
\text { River }\end{array}$ & $\begin{array}{l}\text { Willimantic } \\
\text { River }\end{array}$ \\
\hline Surveyed length (km) & 1.03 & 0.57 & 1.74 & 0.94 & 1.53 & 4.77 & 5.7 \\
\hline Watershed area $\left(\mathrm{km}^{2}\right)$ & 2.18 & 2.3 & 6.31 & 6.58 & 8.43 & 88.86 & 242.77 \\
\hline Strahler order & 2 & 2 & 3 & 3 & 3 & 4 & 6 \\
\hline Mean slope $\left(\mathrm{m} \cdot \mathrm{m}^{-1}\right)$ & 0.06 & 0.1 & 0.03 & 0.04 & 0.03 & 0.01 & 0.009 \\
\hline $\begin{array}{l}\text { Mean bankfull channel width } \\
\text { (m) }\end{array}$ & 4.41 & 4.22 & 7.73 & 4.26 & 4.91 & 8.62 & 30.3 \\
\hline $\begin{array}{l}\text { Mean bankfull channel depth } \\
\text { (m) }\end{array}$ & 0.34 & 0.43 & 0.49 & 0.37 & 0.45 & 0.55 & Not measured \\
\hline $\mathrm{N}$ reaches & 31 & 7 & 27 & 32 & 20 & 41 & 17 \\
\hline $\mathrm{N}$ pieces in channel & 145 & 101 & 236 & 145 & 241 & 671 & 137 \\
\hline $\mathrm{N}$ pieces in active floodplain & 32 & 0 & 18 & 12 & 1 & 38 & 6 \\
\hline $\mathrm{N}$ pieces total & 177 & 101 & 254 & 157 & 242 & 709 & 143 \\
\hline $\mathrm{N}$ jams & 54 & 29 & 94 & 43 & 94 & 244 & 31 \\
\hline Mean length (m) & 4.14 & 3.25 & 6.32 & 6.84 & 7.42 & 4.79 & 7.38 \\
\hline Mean diameter $(\mathrm{cm})$ & 13.84 & 14.73 & 13.69 & 14.75 & 15.86 & 21.65 & 19.65 \\
\hline Volume $\left(\mathrm{m}^{3}\right.$ per $\left.100 \mathrm{~m}\right)$ & 1.63 & 1.8 & 3 & 4.71 & 4.59 & 5.38 & 1.74 \\
\hline Pieces/100 m & 17.19 & 17.8 & 14.62 & 16.65 & 13.8 & 14.88 & 2.51 \\
\hline $\mathrm{Jam} / 100 \mathrm{~m}$ & 5.24 & 5.11 & 5.41 & 4.56 & 5.36 & 5.12 & 0.54 \\
\hline
\end{tabular}


and $157.5-202.5^{\circ}$, perpendicular (B) $67.5-112.5^{\circ}$ and

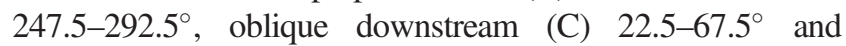
$292.5-337.5^{\circ}$ and oblique upstream (D) $112.5-157.5^{\circ}$ and 202.5-247.5 (e.g. Schuett-Hams et al., 1999; Magilligan et al., 2008). Location of the LWD was inventoried and categorized as follows: (i) in channel, those that are completely unattached from the banks; (ii) ramps, with one side of the LWD resting on a bank; (iii) bridging, with the LWD resting fully on the channel's banks; and (iv) in the active flood plain as wood that is completely out of water and not bridging the channel. Wood load was calculated as pieces per square meter, and wood frequency was calculated as pieces per $100 \mathrm{~m}$.

Jams are considered herein as accumulations of two or more pieces of LWD; if a jam was present, the number of pieces in the jam was recorded as well as the percentage of channel area obstructed by the jam. Stream blockage was estimated using segment average channel depths and widths as well as the length of the key member piece of woody debris in the jam. We also evaluated the longitudinal distribution of wood by using GPS to document the location of each piece of wood in each study reach. Within ArcGIS, study reaches were divided into 25-m long segments (sensu Wohl and Jaeger, 2009), and segment averaged gradients were recorded in the field with clinometers.

\section{RESULTS}

\section{Large woody debris piece characteristics}

A total of 1783 LWD pieces were inventoried in the over $16 \mathrm{~km}$ of sampled stream reaches. The average wood frequency is 13.9 pieces per $100 \mathrm{~m}$, with a rage of 2.51-17.8 pieces per $100 \mathrm{~m}$ (Table I). The largest ordered stream, the Willimantic River, had the lowest wood frequency, and the two second order streams, School House Brook and Goodwin Brook, had the highest frequencies of wood, with 17.19 and 17.8 pieces per $100 \mathrm{~m}$, respectively.

Large woody debris diameters ranged from 13.17 to $21.6 \mathrm{~cm}$ (Figure 2a) with the LWD diameters of the Fenton and Willimantic Rivers significantly different $(p<0.01)$ from other inventoried streams but not significantly different from each other ( $p$ 0.39). LWD lengths ranged from 3.25 to $7.42 \mathrm{~m}$ (Figure $2 \mathrm{~b}$ ) with no significant relationship between wood lengths and stream orders $(p>0.05)$. Wood volume

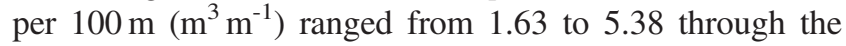
river reaches, with an average of 3.26 (Table I). The third and fourth order streams, Eldridge Brook, Yale Forest, Beaver Dam Brook, and the Fenton River, have the largest wood volumes per $100 \mathrm{~m}$. The smallest as well as the largest ordered streams inventoried in this study have the lowest wood volumes. Wood load (pieces per square meter channel) decreases with channel width (Figure 2c) and increases with average gradient (Figure 2d) at the segment scale.

As watershed area increases, wood tends to be either fully contained within the channel or positioned as ramps, with very few bridging pieces observed (Figure 3). Goodwin Brook and Yale Forest were the only watersheds dominated by ramps. The Willimantic River had, by far, the greatest percent of wood fully contained to the channel and had no wood bridging the channel. The Fenton River, the second largest ordered stream, had the second lowest amount of wood bridging the channel as was also dominated by wood that was fully contained to the channel. The low order river reaches had the largest proportions of LWD in the floodplain or bridging the channel. The reaches surveyed in this study were typically dominated by parallel LWD orientations (orientation A), with the exception of the Fenton River where more LWD was oriented perpendicular (orientation B) to the channel (Figure 4). In general LWD orientations were primarily unidirectional in larger streams and multidirectional in smaller streams.

\section{Jam characteristics}

The Willimantic River had the lowest jam frequency of 0.54 jams per $100 \mathrm{~m}$, whereas the other watersheds ranged from 4.56 to 5.41 per $100 \mathrm{~m}$ (Table I). All watersheds were dominated by debris jams that were two to five pieces in size (Figure 5). Although the Willimantic River had the lowest proportion of debris jams, it had the highest proportion of the largest jam class, 16+ pieces. Eldridge Brook had the largest proportion of mid-sized jams between 6-10 and 11-15 pieces. Key member LWD pieces were measured for their lengths and diameters. The lengths of the key members range from 3.75 to $9.39 \mathrm{~m}$. Key member jam pieces tended to be larger than the average LWD size in a given sampling segment (Figure 6), with the exception of School House Brook. Eldridge Brook, Yale Forest and the Willimantic River all had key members over $0.6 \mathrm{~m}$ longer than the average LWD for each respective reach. The concentration of LWD pieces into jams decreased as both channel gradient and watershed area increased (Figure 7). The overall longitudinal distribution of LWD from upstream to downstream was influenced by local channel slope; high slope reaches contain low numbers of LWD pieces, but after transitions from high to lower slope reaches, there are large peaks in the number of LWD pieces (Figure 8).

\section{DISCUSSION AND CONCLUSION}

This study documents wood loadings in Connecticut streams that rank among the lowest reported nationally. Cordova et al. (2007) conducted a comprehensive review of published LWD frequencies from a number of regions 
(a)

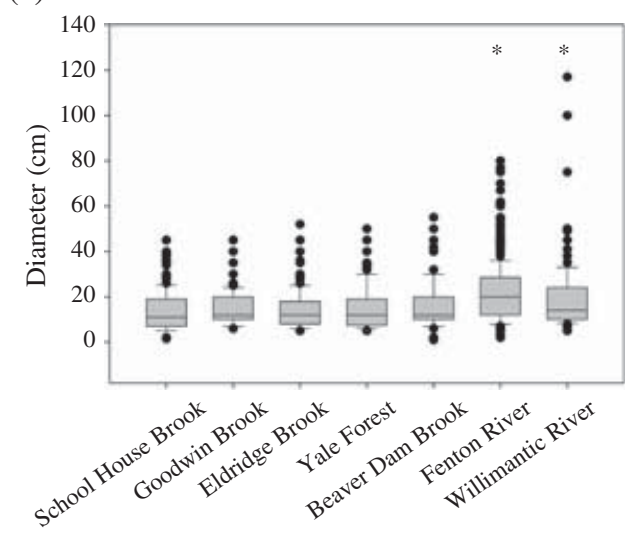

(c)

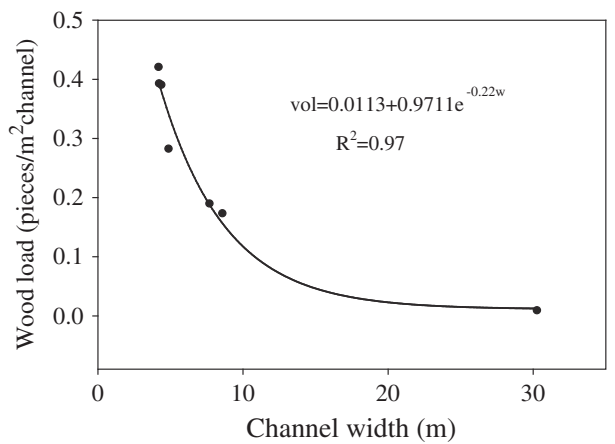

(b)

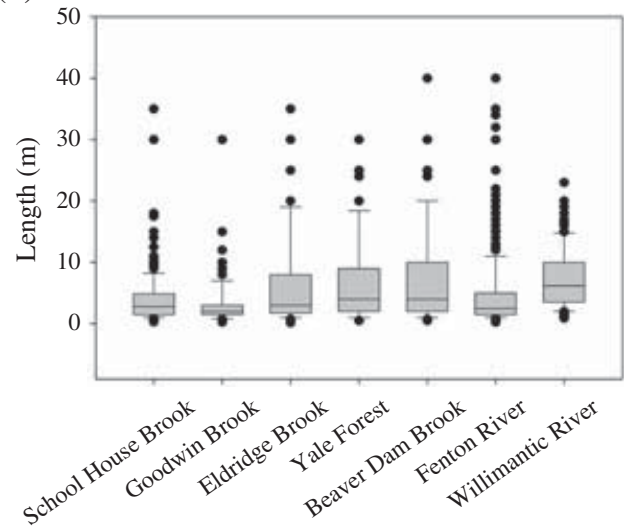

(d)

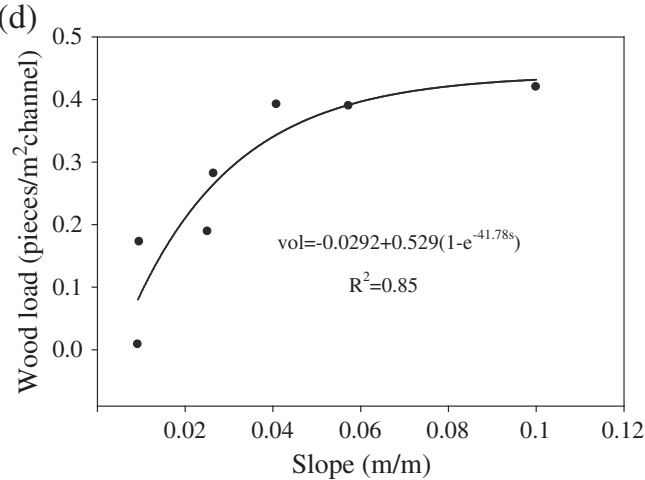

Figure 2. Large woody debris box plots of (a) diameter and (b) length, and wood load in relation to (c) channel width and (d) slope at the watershed scale, watershed size increases to the right ( $\mathrm{a}$ and $\mathrm{b}) . \mathrm{A} *$ dentoes that the sites are significantly different from the other sites $(\mathrm{p}<0.01)$ but not significantly different from each other. For the box plots, the line within each box signifies the median value and the ends are the 25 th and 75th percentiles, whiskers are the 10th and 90th percentiles, and the dots are extreme values

throughout the USA, and Cadol et al. (2009) also published a review of LWD frequencies in old growth forests for a number of regions and countries, but none were available from Northeastern or New England states. Our Connecticut

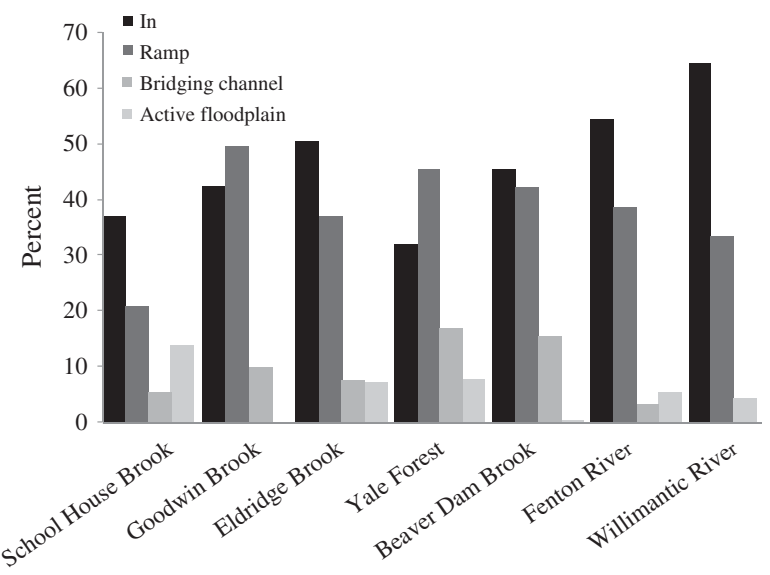

Figure 3. Channel position of the LWD pieces with watershed size increasing to the right survey produced LWD loadings (2.51-17.8 pieces per $100 \mathrm{~m}$ ) lower than those in most of the US regions reviewed in Cordova et al. (2007), with the exception of the Southeast and Central regions of the USA (Georgia, North Carolina,

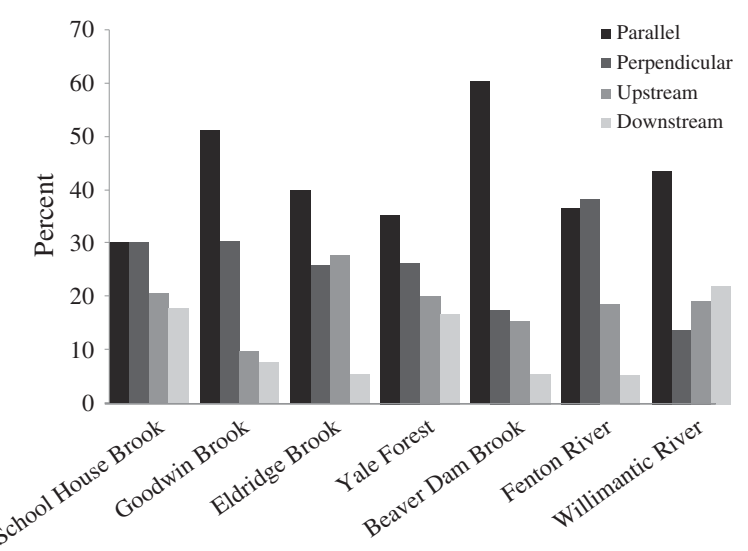

Figure 4. Orientation to flow for LWD by watershed with increasing watershed size to the right

River Res. Applic. 29: 161-171 (2013)

DOI: $10.1002 /$ rra 


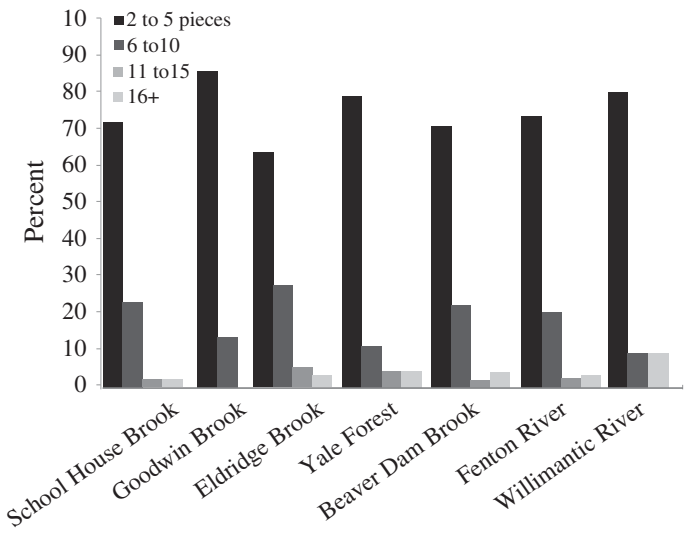

Figure 5. Size classification of woody debris jams with watershed size increasing to the right

Tennessee and Virginia) where abundances ranged from 0.4 to 16.3 per $100 \mathrm{~m}$ and volumes ranged from 0.25 to $3 \mathrm{~m}^{3}$ per $100 \mathrm{~m}^{2}$. This in unsurprising because the Southeast has experienced similar land cover transformations to the Northeast, and the Central region was never heavily forested. In contrast, Upper Midwest abundance ranges from 9 to 64, with an average of 32.6 pieces per $100 \mathrm{~m}$, with volume ranging from 0 to 3.12 , with an average of $0.77 \mathrm{~m}^{3}$ per $100 \mathrm{~m}^{2}$; Alaska abundance ranges from 8 to 40.9 , with an average of 25.1 pieces per $100 \mathrm{~m}$, with volume ranging from 0.36 to 18.02 , with an average of $4.27 \mathrm{~m}^{3}$ per $100 \mathrm{~m}^{2}$; West and West North Central United States (California and Montana) abundance ranges from 5.2 to 91.2 , with an average of 32.6 pieces per $100 \mathrm{~m}$, with volume ranging from 0.03 to 5.2 , with an average of $1.71 \mathrm{~m}^{3}$ per $100 \mathrm{~m}^{2}$; Pacific Northwest (Oregon and Washington) abundance ranges from 0.5 to 239 , with an average of 36.2 pieces per 100 meters, with volume ranging from 0.1 to 8.12 , with an average of $5.04 \mathrm{~m}^{3}$ per
$100 \mathrm{~m}^{2}$; and Mid-Atlantic (Pennsylvania and West Virginia) abundance ranges from 6 to 34, with an average of 16.1 pieces per $100 \mathrm{~m}$ (Cordova et al., 2007).

Our Connecticut findings are similar to those observed in other more recent studies of wood loading in the Northeastern USA (Magilligan et al., 2008; Warren and Kraft, 2008; Laser et al., 2009; Warren et al., 2009). Wood frequencies reported in coastal Maine were 3.2-11.5 pieces per $100 \mathrm{~m}$ for pieces equal or greater to $10 \mathrm{~cm}$ in diameter (Magilligan et al., 2008), and wood frequencies of inland Maine are 7.78 pieces per $100 \mathrm{~m}$ (Laser et al., 2009). Although our observed wood loadings are comparable to those reported by Magilligan et al. (2008) and Laser et al. (2009), wood lengths and diameters varied considerably more. Laser et al. (2009) report wood lengths with a mean of $5.62 \mathrm{~m}$ and a SD of $2.47 \mathrm{~m}$ and mean diameters of $0.21 \mathrm{~m}$ and a SD of $0.11 \mathrm{~m}$, Magilligan et al. (2008) report wood lengths with a mean averaging between 5 and $6.2 \mathrm{~m}$ and a $\mathrm{SD}$ of at most $1 \mathrm{~m}$ and mean diameters averaging between 0.17 and $0.21 \mathrm{~m}$ and a SD of at most 0.03 , whereas the Connecticut streams inventoried here have a mean length of $5.6 \mathrm{~m}$ and a SD of $6.36 \mathrm{~m}$ and mean diameter of $0.12 \mathrm{~m}$ and a SD of $0.18 \mathrm{~m}$. Measured LWD jam frequencies also were quite low and comparable to other studies in the Northeast (Warren et al., 2009). The differences in size of LWD between Connecticut and Maine are likely because of the stochastic weather events more common in coastal Maine (e.g. ice storms and hurricanes) (Laser et al., 2009), slow maturation of trees in coastal Maine (Laser et al., 2009) and continued timber harvesting (Magilligan et al., 2008), all of which produce recruited wood that is much smaller than reported herein for Connecticut. LWD frequency tended to decrease with increasing stream size, which is consistent with previous findings from across the USA (Bilby and Ward, 1989; Montgomery et al., 1995).

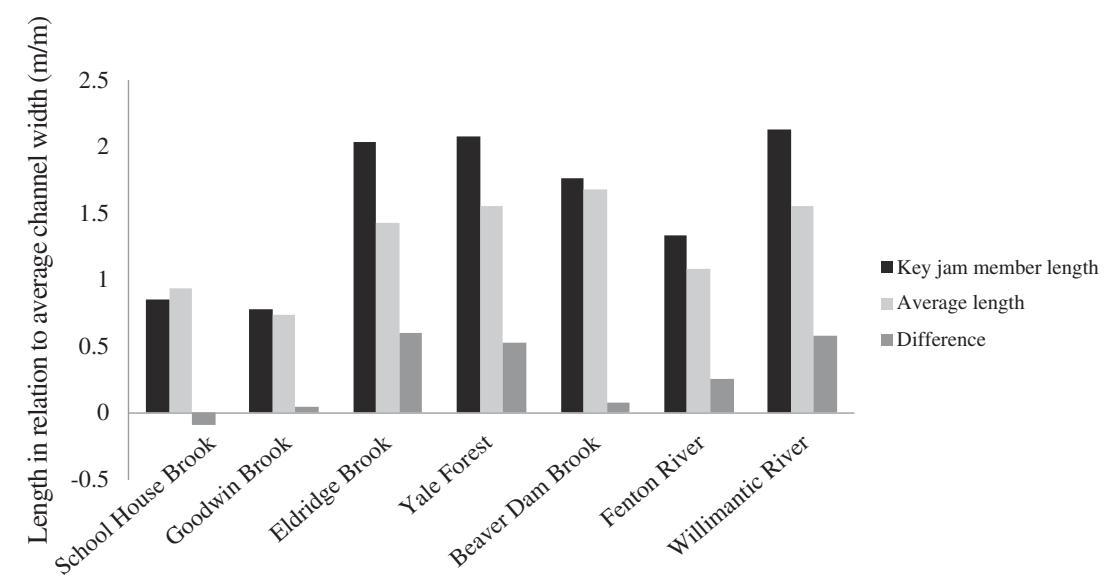

Figure 6. Jam key memeber length, average length, and difference in lengths as a proportion of average channel lengths at the segment scale by watershed where watershed size increases to the right 

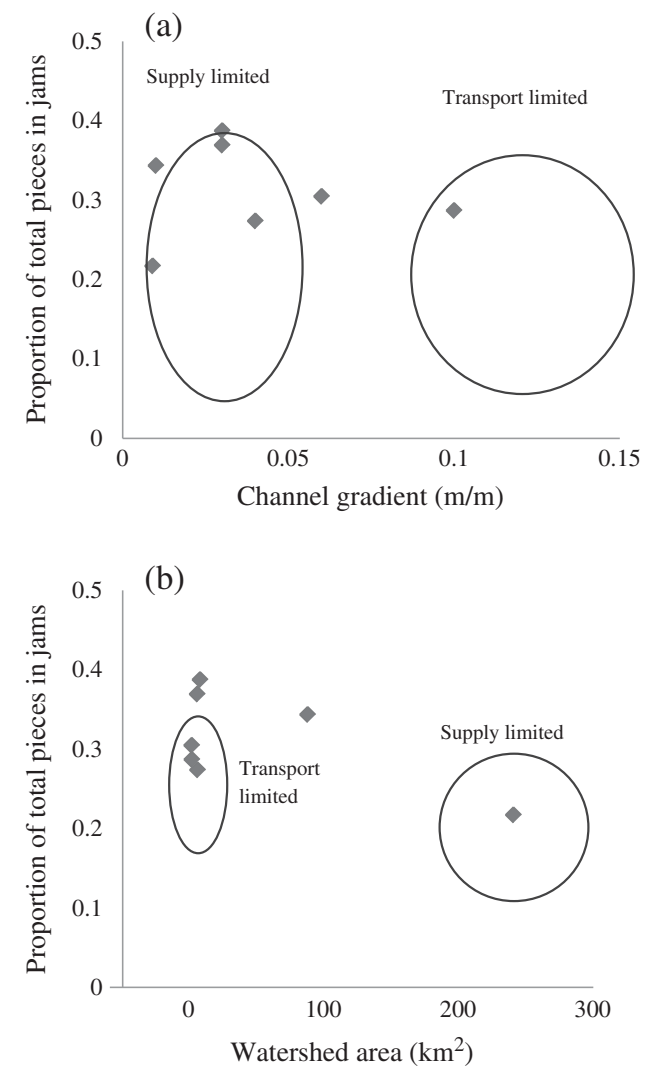

Figure 7. Proportion of total pieces of wood in jams at the segment scale that are supply or transported in relation to (a) channel gradient and (b) watershed as defined by Wohl and Jaeger (2009)

In all of our study reaches, regardless of stream order, LWD pieces were dominated by parallel orientations (Figure 4), but small-sized and intermediate-sized streams did have higher proportions of wood perpendicular to flow, a finding similar to that of Magilligan et al. (2008). Laser et al. (2009) also reported the majority of LWD in downstream or parallel orientations, both of which are unstable and not conducive to retention of organic matter and sediments. The preponderance of unstable orientations suggests that the majority of LWD in Connecticut streams is small enough to be mobilized and transported by these systems.

The predominance of fully contained wood and ramped wood pieces, combined with the absence of bridging pieces (Figure 3), also is likely a result of the low recruitment of large mature trees. Woods introduced into the stream channels are simply too small to effectively bridge channels and/or resist transport by the stream. Other studies have demonstrated that retention of smaller than channelspanning pieces may be dependent on the presence of large anchored pieces of LWD, such as trees with intact soil-root boles (e.g. Daniels, 2006). In the absence of such structures, all but the largest LWD pieces may be transported and redeposited into parallel or ramped configurations as flow subsides. With orientations that are predominantly parallel to flow and low wood volumes, it is highly likely that these streams are not effectively retaining organic matter and fine sediment (Magilligan et al., 2008).

The most plausible explanation for these finding is low wood recruitment from riparian forests, which can be attributed to two primary factors: (i) the history of land use/land cover change resulting in young riparian forests containing trees of considerably smaller size; and (ii) the lack of steep riparian slopes (Magilligan et al., 2008), which limits the systems' ability to recruit wood through debris flow or mass wasting processes. Furthermore, because wood that is recruited to stream channels in the Northeast is primarily from natural mortality and branch fall in young forests (Warren and Kraft, 2008), it generally lacks sufficient size to be retained (Magilligan et al., 2008), contributing to overall low wood volumes. In addition, the forest in Laser et al. (2009) is in

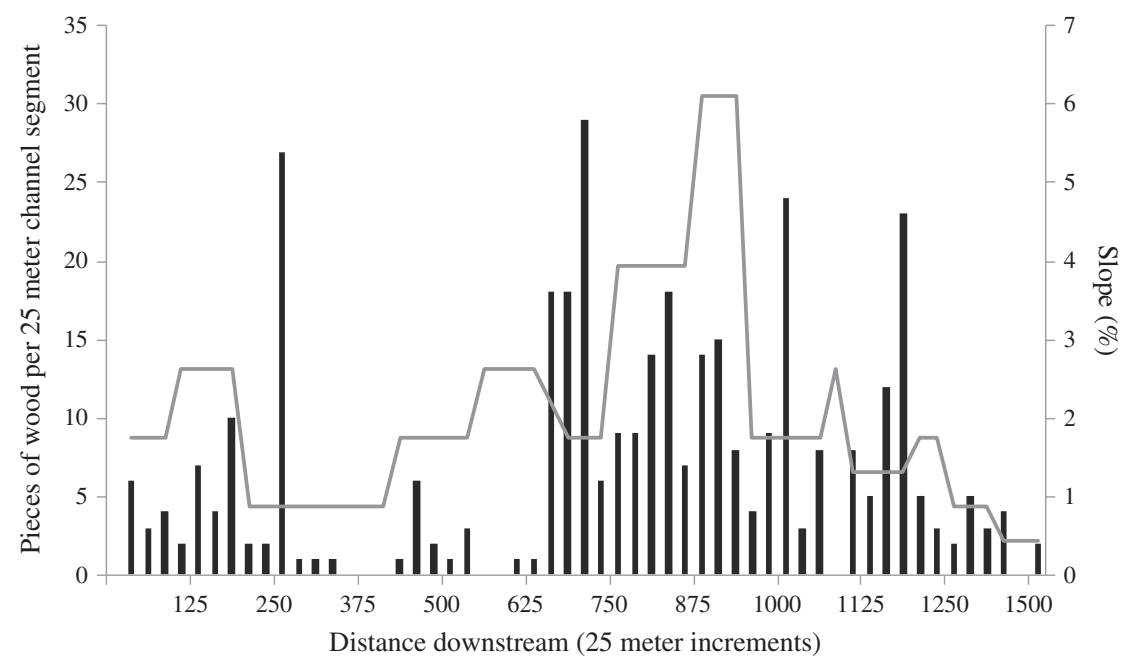

Figure 8. Number of pieces of wood in successive 25 meter increments and the slope of the river at each segment for Beaver Dam Brook 
an intermediate successional state; the trees in their study are more resilient to stochastic weather events, and the wood that is recruited is generally too small to be retained in the system.

Although there is a rich literature set for LWD influence on channel morphology and hydraulics, few studies have examined the longitudinal distribution of wood (Wohl and Jaeger, 2009). Wohl and Jaeger (2009) developed a conceptual model that suggests a progressive decrease in wood load as a response to drainage area, elevation, channel width, bed gradient and total stream power and suggest that the intermediate size streams should have the maximum number of jams. Because of strong local influences, the results of our study do not follow this conceptual model, with small and intermediate streams having relatively similar jam loads (Table I). In using the Wohl and Jaeger (2009) slope criteria, one stream is transport limited, and three are supply limited (Figure 7a); in using their watershed area criteria, one stream is supply limited, and three are transport limited (Figure 7b). The longitudinal distribution of LWD from upstream to downstream appears to be patchy and strongly influenced by slope; high slope segments contain low numbers of LWD pieces, but after transitions from high to lower slope segments, there are large peaks in the number of LWD pieces (Figure 8). However, with limited sample sizes, it is difficult to draw any firm conclusions regarding the wider applicability of the Wohl and Jaeger (2009) model. Our results for the longitudinal distribution of wood through Beaver Dam Brook (Figure 8) indicate that, in addition to riparian forest condition, the segment averaged slope is likely a locally important determinant of wood loading at discrete segment scales.

In summary, our findings support the suggestion by others (Magilligan et al., 2008; Laser et al., 2009) that wood loads and debris jams in the New England region are still being influenced by the land clearing of the 18th and 19th centuries. Although no pre-European settlement data about LWD exists for this region (Magilligan et al., 2008), it is widely recognized that the addition of woody debris to streams in this region will contribute to the quality of the streams both ecologically (Neumann and Wildman, 2002) and geomorphically (Magilligan et al., 2008; Warren et al., 2009). The implications of these findings are important for stream management and restoration efforts throughout Southern New England. Clearly, given what we know about the positive effects of wood in stream channels, the relative scarcity of LWD is likely limiting stream ecosystem function and should be a primary target for river restoration and management efforts. Efforts to increase wood loading in New England streams could include felling selected mature trees into the stream to retentive, stable, configurations (perpendicular to flow, cabled to one back, pinned in place with natural boulders, etc.), constructing jams using in-steam wood retention structures such as wood piles and protecting riparian forests to encourage continued regrowth and natural recruitment (Laser et al., 2009).

\section{ACKNOWLEDGEMENTS}

The authors are thankful for field support from Mike Boyer, Lauren Byron, Krystal Kliger, Ariel Newman and Tom Van Acker. Much of this research was conducted while the authors were affiliated with the Department of Natural Resource Management and Engineering (now the Department of Natural Resources and the Environment) and the Department of Geography at the University of Connecticut.

\section{REFERENCES}

Abbe TB, Montgomery DR. 1996. Large woody debris jams, channel hydraulics and habitat formation in large rivers. Regulated Rivers: Research and Management 12: 201-221.

Abrams J, Riley E. 2002. A reconstruction of the biodiversity of the Connecticut River valley using fossil and geological history evidence. The Traprock 1: 18-22.

Assani AA, Petit F. 1995. Log-jam effects on bed-load mobility from experiments conducted in a small gravel-bed forest ditch. Catena $\mathbf{2 5}$ : 117-126. DOI: 10.1016/0341-8162(95)00004-C

Bilby RE, Likens GE. 1980. Importance of organic debris dams in the structure and function of stream ecosystems. Ecology 61(5): 1107-1113.

Bilby RE, Ward JW. 1989. Changes in characteristics and function of woody debris with increasing size of streams in western Washington. Transactions of the American Fisheries Society 118: 368-378.

Beisel JN, Usseglio-Polatera P, Moreteau J. 2000. The spatial heterogeneity of a river bottom: a key factor determining macroinvertebrate communities. Hydrobiologia 422/423: 163-171. DOI: 10.1023/A:1017094606335

Benda L, Miller D, Sias J, Martin D, Bilby R, Veldhuisen C, Dunne T. 2003. Wood recruitment processes and wood budgeting. American Fisheries Society Symposium 37: 49-73..

Bernhardt ES, Palmer MA, Allan JD, Alexander G, Barnas K, Carr J, Clayton S, Dahm C, Follstad-Shah J, Galat D, Goodwin P, Hart D, Hassett B, Jekinson R, Katz S, Kondolf GM, Lake PS, Lave R, Meter JL, O'Donnell TK, Pagano L, Powell B, Sudduth E. 2005. Ecology synthesizing US river restoration efforts. Science 308: 636-637.

Buffington JM, Lisle TE, Woodsmith RD. 2002. Controls on the size and occurrence of pools in coarse-grained forest rivers. River Research and Applications 18: 507-531. DOI: 10.1002/rra.693

Bragg DC. 2000. Simulating catastrophic and individualistic large woody debris recruitment for a small riparian system. Ecology 81: 1383-1394. DOI: 10.1890/0012-9658(2000)081[1383:SCAILW]2.0.CO;2

Cadol D, Wohl E, Goode JR, Jaeger KL. 2009. Wood distribution in neotropical forested headwater streams of La Selva, Costa Rica. Earth Surface Processes and Landforms 34(9): 1198-1215.

Cadol D, Wohl R. 2011. Coarse sediment movement in the vicinity of a logjam in a neotropical gravel-bed stream. Geomorphology 128: 191-198. DOI: 10.1016/j.geomorph.2011.01.007

CLEAR. 2006. The Status of Connecticut's Riparian Corridors. University of Connecticut. College of Agriculture and Natural Resources. http:// clear.uconn.edu/publications/research/Statewide_riparian_final.pdf

Comiti F, Andreolia A, Lenzia MA, Mao L. 2006. Spatial density and characteristics of woody debris in five mountain rivers of the Dolomites (Italian Alps). Geomorphology 78(1-2): 44-63. DOI: 10.1016/j.geomorph.2006.01.021

Cordova JM, Rosi-Marshall EJ, Yamamuro AM, Lamberti GA. 2007. Quantity, controls and functions of large woody debris in Midwestern 
USA streams. River research and applications 23: 21-33. DOI: 10.1002/ rra.963

Cummins KW, Sedell JR, Swanson FJ, Minshall GW, Fisher SG, Cushing CE, Patterson RC, Vannote RL. 1983. Organic matter budgets for stream ecosystems: Problems in their evaluation. In Stream Ecology: Application and Testing of General Ecological Theory, Barnes JR, Minshall GW (eds). Plenum Press: New York; 299-353.

Daniels MD. 2006. Distribution and dynamics of large woody debris and organic matter in a low-energy meandering stream. Geomorphology 77 : 286-298. DOI: 10.1016/j.geomorph.2006.01.011

Fetherston KL, Naiman RJ, Bilby RE. 1995. Large woody debris, physical process, and riparian forest development in montane river networks of the Pacific Northwest. Geomorphology 13: 133-144. DOI: 10.1016/ 0169-555X(95)00033-2

Fuller TL, Foster DL, McLauchlan TS, Drake N. 1998. Impact of human activity on regional forest composition and dynamics in central New England. Ecosystems 1(1): 76-95.

Friedman JM, Osterkamp WR, Lewis Jr WM 1996. The role of vegetation and bed-level fluctuations in the process of channel narrowing. Geomorphology 14(1): 341-351. DOI: 10.1016/0169-555X(95)00047-9

Gippel CJ. 1995. Environmental hydraulics of large woody debris in streams and rivers. Journal of Environmental Engineering 121(5): 388-395.

Gippel CJ, Finlayson BL, O'Neill IC. 1996. Distribution and hydraulic significance of large woody debris in a lowland Australian river. Hydrobiologia 318: 179-194. DOI: 10.1007/BF00016679

Gregory KJ, Gurnell AM, Hill CT, Tooth S. 1994. Stability of the poolriffle sequence in changing river channels. Regulated Rivers: Research and Management 9: 35-43.

Gurnell AM. 1995. Vegetation along river corridors: hydrogeomorphological interactions. In Changing River Channels, Gurnell G, Petts G (eds). John Wiley and Sons Ltd: Chichester.

Gurnell AM, Gregory KJ, Petts GE. 1995. The role of coarse woody debris in forest aquatic habitats: implications for management. Aquatic Conservation: Marine and Freshwater Ecosystem 5: 143-166.

Gurnell AM, Sweet R. 1998. The distribution of large woody debris accumulations and pools in relation to woodland stream management in a small, low-gradient, stream. Earth Surface Processes and Landforms 23: $1101-1121$.

Kasprak A, Magilligan FJ, Nislow KH, Snyder NP. 2011. A LIDARderived evaluation water watershed-scale large woody debris sources and recruitment mechanisms: coastal Maine, USA. River Research and Applications DOI: 10.1002/rra.153.

Keller EA, Swanson FJ. 1979. Effects of large organic material on channel form and fluvial processes. Earth Surface Processes 4: 361-380.

Keller EA, Tally T. 1979. Effects of large organic debris on channel form and fluvial processes in the coastal redwood environment. In Adjustments in the fluvial system, Rhodes DD, Williams GP (eds). Kendell Hunt Publications: Dubuque, IA; 168-198.

Kondolf GM. 1995. Five elements for effective evaluation of stream restoration. Restoration Ecology 3: 133-136. DOI: 10.1111/j.1526-100X. 1995.tb00086.x

Koteff C, Stone JR, Larsen FD, Ashley GM, Boothroyd JC, Dincauze DF. 1988. Glacial Lake Hitchcock, postglacial uplift and postlake archeology. In Field trip guidebook American Quaternary Association 1988, Brigham-Grette J (ed.). University of Massachusetts Department of Geology and Geography Contribution 63.

Lamberti GA, Gregory SV, Ashkenas LR, Wildman RC, Steinman AD. 1989. Influence of channel geomorphology on retention of dissolved and particulate matter in a Cascade Mountain stream. In Proceedings of the California Riparian Systems Conference: Protection, Management, and Restoration for the 1990s. Pacific Southwest Forest and Rance Experiment Station, Forest Service, U.S. Department of Agriculture: Berkeley.
Laser M, Jordan J, Nislow K. 2009. Riparian forest and in stream large wood characteristics, West Branch Sheepscot River, Maine, USA. Forest Ecology and Management 257(7): 1558-1565. DOI: 10.1016/j. foreco.2008.12.024

Lester RE, Wright W, Jones-Lennon M. 2007. Does adding wood to agricultural streams enhance biodiversity? An experimental approach. Marine and Freshwater Research 58(8): 687-698. DOI: 10.1071/MF06198

Leopold L. 1994. A View of the River. Harvard University Press: Cambridge, MA.

Lienkaemper GW, Swanson FJ. 1987. Dynamics of large woody debris in streams in old-growth Douglas-fir forests. Canadian Journal of Forest Research 17(2): 150-156.

Lisle TE. 1995. Effects of coarse woody debris and its removal on a channel affected by the 1980 eruption of Mount St. Helens, Washington. Water Resources Research 31(7): 1797-1808. DOI: 10.1029/95WR00734.

Magilligan FJ, Nislow KH, Fisher GB, Wright J, Mackey G, Laser M. 2008. The geomorphic function and characteristics of large woody debris in low gradient rivers, coastal Maine, USA. Geomorphology 97: 467. DOI: 10.1016/j.geomorph.2007.08.016

Magna M, Kirchner JW. 2000. Stress partitioning in streams by large woody debris. Water Resources Research 36(8): 2373-2379. DOI: 0043-1397/00/2000WR900153

Maser C, Sedell JR. 1994. From the Forest to the Sea: The Ecology of Wood in Streams, Rivers, Estuaries, and Oceans. St. Lucia Press: Delray Beach.

McCusker MH, Daniels MD. 2009. The potential influence of small dams on basin sediment dynamics and coastal erosion in Connecticut. Middle States Geographer 41: 82-90.

Meyer JL, Strayer DL, Wallace JB, Eggert SL, Helfman GS, Leonard NE. 2007. The contribution of headwater streams to biodiversity in river networks. Journal of the American Water Resources Association 43: 86-103.

Miller DR, Warner GS, Ogden FL, DeGaetano AT. 2002. Precipitation in Connecticut. Special Reports. Paper 36.

Montgomery DR, Buffington JM, Smith RD, Schmidt KM, Press G. 1995. Pool spacing in forest channels. Water Resources Research 31(4): 1097-1105.

Montgomery DR, Collins BD, Buffington JM, Abbe TB. 2003. Geomorphic effects of wood in rivers. American Fisheries Society Symposium 37: 21-47.

Motzkin G, Patterson WA, Foster DR. 1999. A historical perspective on pitch pine-scrub oak communities in the Connecticut Valley of Massachusetts. Ecosystems 2(3): 255-273.

Myers T, Swanson S. 1997. Variability of pool characteristics with pool type and formative feature on small Great Basin rangeland streams. Journal of Hydrology 201: 62-81. DOI: 10.1016/S0022-1694(97)00032-2

Nakamura F, Swanson FJ. 1993. Effects of coarse woody debris on morphology and sediment storage of a mountain stream system in western Oregon. Earth Surface Processes and Landforms 18: 43-61. DOI: 10.1002/ esp.3290180104.

Nilsson C, Jansson R, Malmqvist B, Naiman RJ. 2007. Restoring riverine landscapes: the challenge of identifying priorities, reference states, and techniques. Ecology and Society 12: 1708-3087.

Nuemann RM, Wildman TL. 2002. Relationships between trout habitat use and woody debris in two southern New England streams. Ecology of Freshwater Fish 11: 240-250. DOI: 10.1034/j.1600-0633.2002.00016.x

Piégay H, Thevenet A, Citterio A. 1999. Input, storage and distribution of large woody debris along a mountain river continuum, the Drome River, France. Catena 35(1): 19-39. DOI: 10.1016/S0341-8162(98)00120-9

Raikow DF, Grubbs SA, Cummins KW. 1995. Debris dam dynamics and coarse particulate organic matter retention in an Appalachian mountain stream. Journal of the North American Benthological Society 14: $535-546$. 
Ralph SC, Poole GC, Conquest LL, Naiman RJ. 1994. Stream channel morphology and woody debris in logged and unlogged basins of western Washington. Canadian Journal of Fisheries and Aquatic Sciences 51: 37-51. DOI: $10.1139 / \mathrm{f} 94-006$

Richmond AD, Fausch KD. 1995. Characteristics and function of large woody debris in subalpine Rocky Mountain streams in northern Colorado. Canadian Journal of Fisheries and Aquatic Sciences 52: 1789-1802. DOI: 10.1139/f95-771

Robinson EG, Beschta RL. 1990a. Characteristics of coarse woody debris for several coastal streams of southeast Alaska, USA. Canadian Journal of Fisheries and Aquatic Sciences 47(9): 1684-1693. DOI: 10.1139/ f90-193

Robinson EG, Beschta RL. 1990b. Coarse woody debris and channel morphology interactions for undisturbed streams in southeast Alaska, U.S.A. Earth Surface Processes and Landforms 15: 149-156. DOI: 10.1002/ esp.3290150205

Schuett-Hams D, Pleus AE, Ward J, Fox M, Light J. 1999. TFW monitoring program method manual for the large woody debris survey. NW Indian Fisheries Commission Technical Report TFW-AM8-99-004.33 pg.

Smith RD, Sidle RC, Porter PE. 1993. Effects on bedload transport of experimental removal of woody debris from a forest gravel-bed stream. Earth Surface Processes and Landforms 18: 455-468. DOI: 10.1002/ esp.3290180507

Snyder NP, Castele MR, Wright JR. 2009. Bedload entrainment in low gradient paraglacial coastal rivers of Maine, USA: implications for habitat restoration. Geomorphology 103: 430-446. DOI: 10.1016/j.geomorph.2008.07.013

Stone BD, Borns Jr HW. 1986. Pleistocene glacial and interglacial stratigraphy of New England, Long Island, and adjacent Georges Bank and Gulf of Maine. In Quaternary Glaciations in the Northern Hemisphere, Sibrava V, Bowen DQ, Richmond GM (eds). Pergamon Press: Oxford; 39-52.
Stone JR, Schafer JP, London EH, Lewis RL, DiGiacomo-Cohen ML, Thompson WB. 2005. Quaternary geologic map of Connecticut and Long Island Sound Basin: U.S. Geological Survey Scientific Investigations Map SI-2784, 1:125,000 scale, two sheets

Strahler AN. 1957. Quantitative analysis of watershed geomorphology. American Geophysical Union Transactions 38: 913-920.

Thompson DM. 1995. The effects of large organic debris on sediment processes and stream morphology in Vermont. Geomorphology 11: 235-244. DOI: 10.1016/0169-555X(94)00064-X

Warren CR, Stone BD. 1986. Deglaciation stratigraphy, mode and timing of the eastern flank of the Hudson-Champlain lobe in western Massachusetts. In The Wisconsinan Stage of the First Geological District, Eastern New York, Cadwell DH (ed.). New York State Museum Bulletin Number 455: New York; 168-192.

Warren DR, Kraft CE. 2008. Dynamics of large wood in an eastern US mountain stream. Forest Ecology and Management 256: 808-814. DOI: $10.1016 /$ j.foreco.2008.05.038

Warren DR, Kraft CE, Keeton WS, Nunery JS, Liken GE. 2009. Dynamics of wood recruitment in streams of the northeastern US. Forest Ecology and Management 258: 804-813. DOI: 10.1016/j.foreco.2009.05.020.1

Wilkins BC, Snyder NP. 2010. Geomorphic comparison of two Atlantic coastal rivers: toward an understanding of physical controls on Atlantic salmon habitat. River Research and Applications 27: 135-156. DOI: 10.1002/rra. 134

Wohl E, Angermeier PL, Bledsoe B, Kondolf GM, MacDonnell L, Merritts DM, Palmer MA, Poff NL, Tarboton D. 1995. River restoration. Water Resources Research 41: 1-12. DOI: 10.1029/2005WR003985

Wohl E, Jaeger K. 2009. A conceptual model for the longitudinal distribution of wood in mountain streams. Earth Surface Processes and Landforms 34: 329-344. DOI: 10.1002/esp.1722 